UDC 378.011.3-051:373.3]:378.016:51

DOI https://doi.org/10.31470/2415-3729-2020-12-90-108

\title{
Formation of Research Skills of Future Primary School Teachers in the Process of Teaching Mathematics
}

\section{Yurii Mazhuha}

Doctor of Philosophy in Physics and Mathematics (Ph.D), Senior Lecturer,

Department of Primary Education,

Pedagogical Institute of Borys Grinchenko Kyiv University

$\triangle$ 18/2, I. Shamo blvd., Kyiv, Ukraine, 02154

E-mail: y.mazhuha@kubg.edu.ua

ORCIDiD: http://orcid.org/0000-0001-7988-183X

Date of receipt of the article: September 28, 2020

Article accepted for publication: November 22, 2020

\section{Формування дослідницьких умінь майбутніх учителів початкової школи в процесі навчання математики}

\section{Юрій Іванович Мажуга}

кандидат фізико-математичних наук, старший викладач, кафедра початкової освіти, Педагогічний інститут Київського університету імені Бориса Грінченка

$\triangle$ бул. І. Шамо, 18/2, Київ, Україна, 02154

Дата надходження статті: 28 вересня 2020 р. Стаття прийнята до друку: 22 листопада 2020 р. 


\section{Abstract}

One of the priority tasks of pedagogical education is wide comprehensive training of students, based on the concept of personally oriented education and involves the formation of a holistic system of universal knowledge, skills, as well as experience of independent activities, the basic competencies that determine the quality of education of a modern university student. The purpose of the article is to highlight the problem of formation of research skills of university students, as well as the role of inquiry-based learning approach in solving this problem. The research was based on scientific works of domestic and foreign scientists who studied the formation and development of research skills of students in the learning process. Methods. The author implements the purpose with the help of theoretical and empirical research methods (analysis and generalization of own pedagogical experience and pedagogical experience of domestic and foreign scientists).

The results. The article considers and generalizes the views of scientists on the classification and essence of research skills, analyses the role of the inquiry-based learning approach in the formation of students' research skills in the process of teaching mathematics. The article suggests the effective method on forming the students' research skills based on the studentcentered approach in the process of teaching mathematics (Inquiry-Based Mathematics Education). The special educational material (pedagogical cases) based on IBME was developed. The benefit of the study is that the material was tested during the teaching of mathematics to first-year students of specialty «Primary Education» of the Pedagogical Institute of Borys Grinchenko Kyiv University (the research, the results of which are presented in the article, was conducted within the project «Partnership for teaching and learning of mathematics at the university» (PLATINUM) of the EU program Erasmus + KA203 - Strategic Partnership for Higher Education, 2018-1NO01-KA203-038887); the data show the increase of students' interest in educational and research work, and the level of their motivation to study mathematics. 
Conclusions. As a result the author makes a conclusion that the teaching mathematics with the use of Inquiry-Based Mathematics Education ensures the growth of interest of students in educational and research activity, formation and development of research skills; increases the efficiency of independent work, general motivation for the study of mathematics.

Keywords: research skills, inquiry-based learning, InquiryBased Mathematics Education, formation of research skills of future primary school teachers.

\section{References}

1. Dorier, J.L. \& Maass, K. (2014). Inquiry-Based Mathematics Education. In S. Lerman (Ed.), Encyclopedia of mathematics education. (pp. 300-303). Amsterdam, Holland: Springer.

2. Honcharenko, S.U. (1997). Ukrainskyi pedahohichnyi slovnyk [Ukrainian pedagogical dictionary]. In. S. Holovko (Ed.). Kyiv : Lybid [in Ukrainian].

3. Jaworski, B. (2019). Inquiry-based practice in university mathematics teaching development, In D. Potari and O. Chapman, International Handbook of Mathematics Teacher Education, vol 1, (pp. 275-302), Leiden, The Netherlands: Brill.

4. Mazhugha, Ju.I. (2017). Metodyko-matematychna kompetentnistj majbutnikh uchyteliv pochatkovoji shkoly, vplyv ta znachennja matematychnoji loghiky u jiji formuvanni [Methodological and mathematical competence of future primary school teachers, the impact and importance of mathematical logic in its formation]. Proceedings of the XXIII International scientific and practical internet conference "Trends and prospects for the development of science and education in the context of globalization. Perejaslav-Khmeljnycjkyj. (vol 23, pp. 125-131) [in Ukrainian].

5. Vygotsky, L.S. (1978). Mind in Society: The development of higher psychological processes. Cambridge, MA: Harvard University Press. 
«Уміння - цее майстерність, цее здатність використовувати наявні знання для досягнення своїх изілей ...»

Дьордь Пойа

\section{Вступ}

У сучасних умовах соціально-економічного розвитку України як держави, стрімких змін у сфері педагогічної науки та освітніх технологій особливого значення набуває проблема реформування професійної підготовки майбутніх педагогів.

Одним з пріоритетних завдань педагогічної освіти є широка загальноосвітня підготовка студентів, що базується на концепції особистісно орієнтованого навчання та передбачає формування цілісної системи універсальних знань, умінь, навичок, а також досвіду самостійної діяльності, тобто основних компетентностей, що визначають якість освіти сучасного студента вищого навчального закладу.

Саме компетентнісний підхід дозволить реалізувати головну мету педагогічного ВНЗ - підготовку висококваліфікованого вчителя початкової школи. Професійно-педагогічну спрямованість повинні мати абсолютно всі навчальні предмети, які вивчаються в педагогічному виші, у тому числі - математика. Така спрямованість навчання відображає не лише мету педагогічної освіти, але й їі зміст. Щодо змісту, то студенти не просто засвоюють сукупність наукових і педагогічних знань, але і навчаються застосовувати їх у своїй майбутній педагогічній діяльності, що згодом дозволить досягти високого рівня професійної майстерності (Мажуга, 2017).

Високий рівень професійної підготовки молодого спеціаліста $€$ визначальним фактором подальшої успішної кар'єри у будь-якій сфері педагогічної діяльності, його конкурентоздатності на ринку праці. Саме для досягнення такого рівня сучасний студент повинен оволодіти не лише 
різноманітними знаннями, а й уміннями, які дозволять йому застосовувати набуті знання в процесі самостійної професійної діяльності.

Аналіз психолого-педагогічної і методичної літератури показав, що формування дослідницьких умінь студентів залежить від методів та підходів до організації навчальнопізнавальної та дослідницької діяльності студентів, що знайшло своє відображення у наукових дослідженнях В. Андреєва, Г. Артемчук, В. Буряка, А. Єріної, В. Захожай, М. Князян, І. Кравцової, Н. Мирончук, Л. Моїсєєвої, 3. Слепкань, Є. Спіцина, А. Філіпенко та ін.

Питання професійної підготовки майбутнього педагога до дослідницької діяльності розглядалися в працях О. Абдулліної, В. Бондаря, Л. Виготського, П. Гальперіна, I. Зязюна, С. Мартиненко, Л. Пуховської, О. Савченко, С. Сисоєвої, Л. Хомич, П. Щербаня, Н. Яковлевої та ін.

Проведений аналіз також свідчить про те, що впродовж останніх років вітчизняні та іноземні науковці в своїх дослідженнях значну увагу приділяють проблемі розвитку дослідницьких умінь студентів в процесі викладання певних навчальних дисциплін, у тому числі математики (С. Арсьонова, М. Артіг, С. Гудчайлд, С. Доре, М. Дорф, П. Ернест, А. Карлащук, I. Каташинська, Т. Крофт, М. Ламперт, В. Литовченко, К. Маасс, Дж. Мейсон, С. Раков, I. Соломон, Д. Хайберт, Б. Яворськи та ін.)

Проблемі формування дослідницької компетентності студентів вищих навчальних закладів присвячені наукові дослідження багатьох вітчизняних та іноземних вчених. Разом 3 тим, окремі важливі аспекти вирішення цієї проблеми можуть мати подальший розвиток. Це стосується, зокрема, дослідження змісту, методів і підходів до організації навчання, які б сприяли формуванню та розвитку у студентів дослідницьких умінь та навичок у процесі навчання математики. 
На нашу думку, саме впровадження дослідницькопізнавального підходу до навчання математики у вищих навчальних закладах є актуальним у напрямку орієнтації на формування дослідницьких умінь студентів.

Мета публікації - висвітлити проблему формування дослідницьких умінь у студентів вищих навчальних закладів, роль дослідницько-пізнавального підходу у розв'язуванні цієї проблеми; запропонувати ефективну методику формування навчально-дослідницьких умінь студентів у процесі викладання математики із застосуванням дослідницькопізнавального підходу.

\section{Матеріал і методи досліджень}

Матеріалом для дослідження слугували особисті спостереження та результати опрацювання психологопедагогічної літератури стосовно аналізу змісту понять «дослідницькі уміння» та «навчально-дослідницькі уміння», що дало можливість визначити їх ієрархію в контексті проблеми формування дослідницьких умінь студентів у процесі навчання та запропонувати ефективну методику іï вирішення.

Для досягнення мети були використані такі методи:

- mеоретичні: аналіз, синтез та узагальнення власного педагогічного досвіду та педагогічного досвіду вітчизняних i закордонних науковців щодо проблеми ефективного формування дослідницьких умінь студентів у процесі навчання;

- емпіричні: власні спостереження у процесі навчання математики;

- статистичні: аналіз результатів опитування студентів.

\section{Результати та їх обговорення}

У сучасній науковій, психолого-педагогічній літературі можна зустріти різні означення базових понять «дослідницькі уміння» та «навчально-дослідницькі уміння», що розкривають їх сутність і зміст. 
Український педагогічний словник визначає уміння як «здатність належно виконувати певні дії, заснована на доцільному використанні людиною набутих знань і навичок. Уміння передбачає використання раніше набутого досвіду, певних знань; без останніх немає уміння» (Гончаренко, 1997).

Аналіз психолого-педагогічних джерел показав, що єдиного підходу до визначення сутності та класифікації навчально-дослідницьких умінь не існує. Окремі науковці тлумачать поняття «навчально-дослідницькі уміння», 3 одного боку, як властивість особистості, яка характеризує їі здатність до пошуково-перетворюючої діяльності в освітньому процесі, а з іншого, як ії здатність здобувати нові знання, уміння і навички, які сприяють його професійному розвитку і саморозвитку.

Відомо, що уміння формуються і розвиваються в процесі відповідної діяльності. Основним видом діяльності у вищому навчальному закладі $\epsilon$ навчальна діяльність. Знання і професійні уміння студентів формуються під час вивчення певних навчальних предметів. Тому важливим завданням педагога є така організація навчального процесу, яка б забезпечувала формування знань i навчальнодослідницьких умінь як цілісної системи.

В процесі традиційного підходу до навчання відбувається репродуктивне засвоєння знань, предмет розумових дій задається навчальним матеріалом, який готує і пояснює викладач, а студенти його запам'ятовують і через деякий час відтворюють для оцінювання. Якщо ж створюється предметна ситуація, під час якої студенти мають справу із завданнями пошукового характеру, коли вони повинні самостійно (можливо частково за допомогою партнерів або викладача) здійснити певні кроки для отримання нових знань, використовуючи вже відомі, тоді їх діяльність відбувається у формі дослідницького процесу:

- формулювання питань до предмету дослідження;

- постановка задачі; 
- проведення дослідження;

- формулювання гіпотези;

- розв'язування задачі (отримання нового знання);

- аналіз і оцінювання отриманого результату.

Порівнюючи процес наукової праці вченого і діяльності студента, який розв'язує навчальні завдання дослідницького характеру, можна зазначити, що вони грунтуються на подібних розумових операціях. Різниця між ними полягає переважно у тому, що вони намагаються розв'язувати завдання різного ступеня складності, при цьому вчений, як правило, має значно більше можливостей у використанні методів, способів та інструментів для проведення дослідницької діяльності. Автор підтримує точку зору прихильників підходу, відповідно до якого трактування поняття «дослідницька діяльність» базується на характері педагогічної взаємодії між викладачем та студентом. Якщо викладачу відомий шлях дослідження певної проблеми (розв'язування задачі) і він пропонує студентам самостійно пройти цим шляхом, напевне знаючи розв'язок або передбачаючи очікуваний результат такого дослідження, то така діяльність може визначатися як навчальнодослідницька. Якщо ж викладач володіє різноманітними методами та інструментами наукового дослідження і він знайомить 3 ними студентів, у нього та студентів достатньо розвинуті інтуїція та наукове передбачення, однак їм невідомі ні шляхи проведення дослідження (можливо лише орієнтовні), ні остаточний результат дослідження (розв'язок задачі), то така діяльність може вважатися науководослідницькою.

3 огляду на практику проведення досліджень у вищих навчальних закладах, у тому числі педагогічних, застосування передових інформаційних технологій, форм, методів і підходів до навчання та досвіду роботи зі студентами, можна стверджувати, що в сучасних умовах навчання i, в першу чергу навчання математики, навчально- 
дослідницька діяльність студентів переважає над науководослідницькою. У контексті нашого дослідження ми розглядаємо проблему формування саме навчальнодослідницьких умінь студентів - майбутніх учителів початкової школи в процесі навчання математики, вважаючи ці уміння одним із головних видів професійних умінь педагога.

Процес навчання зазвичай базується на певних психолого-педагогічних теоріях, концепціях i методах навчання, які у свою чергу спираються на виявлені та дослідженні закономірності пізнавальної діяльності особистості і передбачає відповідну модель організації навчань. Найбільш поширеною сучасною освітньою парадигмою є теорія особистісно орієнтованого навчання, в основі якої лежить концепція студентоцентрованого навчання.

Розглянемо більш детально сутність дослідницькопізнавального підходу до навчання. У вітчизняній педагогічній літературі дослідницько-пізнавальний підхід до навчання (inquiry-based learning approach) визначають ще як дослідницький підхід, проблемно-пошуковий підхід до навчання, підхід до навчання на основі запитів, навчання засноване на дослідженнях та ін. Слід також відзначити, що розвиток уявлень про сутність, роль і місце дослідницькопізнавального підходу в навчанні тісно пов' язаний з появою інших конструктивістських освітніх концепцій, зокрема проблемного та проектного навчань .

Найбільш активно дослідницько-пізнавальний підхід, як один із конструктивістських підходів до навчання, почав вивчатись і застосовуватись у останні півтора століття. Теоретичним і практичним підгрунтям розроблення підходу до навчання, заснованого на дослідженні, стали роботи видатних науковців Ж. Піаже, Дж. Дьюї, Л. Виготського, в яких фактично були закладені основи конструктивістської філософії. Аналіз психолого-педагогічних спостережень i 
досліджень, а також власний педагогічний досвід доводять, що задачі дослідницького характеру пробуджують у студентів пізнавальний інтерес, активність, самостійність. При цьому виявляється, що саме мислення в процесі розв’ язування задач дослідницького та пошукового характеру відрізняється від мислення при розв'язуванні задач стандартного характеру. Сутність дослідницькопізнавального підходу полягає у тому, що викладач створює у формі дослідницьких завдань певні проблемні ситуації і задачі, а студенти вирішують їх самостійно або ж частково 3 допомогою викладача, виконуючи при цьому творчий пошук. Саме під час такого пошуку (при якому студенти виконують завдання дослідницького характеру, ставлять питання i формулюють пропозиції, проводять експерименти, висувають гіпотези, перевіряють і доводять правильність цих гіпотез, оцінюють результати проведених досліджень) відбувається формування і розвиток дослідницьких умінь.

Ідея написання даної статті виникла під час роботи автора в рамках міжнародного проекту «Партнерство для навчання та викладання математики в університеті» (PLATINUM) програми СС Еразмус + КА203 - Стратегічне партнерство для вищої освіти, 2018-1-NO01-КА203-038887. Головною метою цього проекту $\epsilon$ покращення рівня математичної освіти у вищих навчальних закладах шляхом впровадження найкращих інноваційних технологій, що базуються на дослідницько-пізнавальному підході до навчання математики (Inquiry-Based Mathematics Education), та формування математичної компетентності студентів в системі STЕM-освіти.

Енциклопедія математичної освіти відносить IBME до студенто-центрованої парадигми навчання математики та природничих наук, в якій студентів запрошують працювати способами, подібними до тих, що використовують математики та науковці. Це означає, що вони повинні спостерігати за явищами, ставити запитання, шукати 
математичні та наукові шляхи відповіді на ці запитання (наприклад, проводити експерименти, систематично контролювати змінні, будувати діаграми, обчислювати, шукати закономірності та зв'язки, робити припущення та узагальнення), інтерпретувати та оцінювати свої рішення, а також ефективно комунікувати та обговорювати отримані результати (Dorier\&Maass, 2014).

Дослідження IBME в природничо-науковій та математичній освіті на рівні початкової та середньої шкіл проведені в процесі реалізації європейських освітніх проектів Fibonacci (www.fibonacci-project.eu), Primas (www.primas-project.eu), MaScil (www.mascil-project.eu) та ін. Однак мало або практично немає досліджень сутності такого підходу до навчання математики на університетському рівні (А. Біза, С. Гудчайлд, В. Жиралдо, Т. Крофт, К. Расмуссен, I. Соломон, А. Хакбаз, Р. Хокмут, Б. Яворськи).

Теоретичний фундамент проекту PLATINUM базується на трирівневій моделі IBME (Jaworski, 2019):

- IBME на рівні викладачів та студентів з використанням спеціально розроблених завдань на базі inquiry (запиту);

- IBME в інноваційних підходах до викладання математики 3 рефлексивним (критичним) аналізом викладацької практики та іiі впливу на концептуальне розуміння студентів;

- IBME як пізнавальний підхід, спрямований на вдосконалення практики в двох попередніх рівнях 3 об'єктивним моніторингом вказаної діяльності викладачами i дослідниками, а також студентами, та встановлення зворотного зв'язку між ними, що посприяє їх спільному зростанню як спільноти (Community of Inquiry).

Педагогічне дослідження щодо формування та розвитку навчально-дослідницьких умінь студентів було здійснено в процесі впровадження IBME у навчання математики студентів першого курсу спеціальності «Початкова освіта» Педагогічного інституту Київського 
університету імені Бориса Грінченка 2019-2020 років навчання. На початковому етапі дослідження було проведено опитування 42 студентів 3 метою визначення загального рівня мотивації до навчання, схильності до самостійної роботи, зацікавленості у формуванні дослідницьких умінь в процесі навчання математики. Аналіз результатів опитування засвідчив, що загальний рівень мотивації до навчання студентів виявився, в основному, середнім (67\%); рівень зацікавленості у вивченні математики також переважно середній (61\%); однакова кількість студентів готова висловлювати свої ідеї, припущення для розв'язування або звернеться за підказкою до викладача, якщо виникають труднощі при розв'язуванні задачі (36\%). Разом із тим більшості студентів подобаються завдання пошукового характеру (81\%); абсолютна більшість зацікавлена у розвитку дослідницьких умінь в процесі навчання математики (83\%).

Автор переконаний, що необхідним елементом ефективної реалізації IBME $\epsilon$ забезпечення диференційованого або особистісно орієнтованого підходу до навчання. Головна мета - створити сприятливі умови для навчання кожного студента. Вона включає: вивчення індивідуальних особливостей студентів, рівня їх математичної підготовки, того, що Л.Виготський визначав як «зона найближчого розвитку» (Vygotsky, 1978). Кожному заняттю 3 математики із використанням дослідницькопізнавального підходу передували відповідна підготовча робота та планування. В якості основи розробки сценарію проведення занять були обрані навчальна модель 5Е (https://bscs.org/bscs-5e-instructional-model/) структурований запит 3 використанням відповідних регуляторних карток (https://www.inquirymaths.com).

Навчальна модель 5E (Engage, Explore, Explain, Elaborate, Evaluate) базується на когнітивній психології, конструктивістській теорії навчання та кращих практиках 
навчання STEM. Навчальний цикл 5E проводить студентів через п'ять етапів: Залучення, Дослідження, Пояснення, Отримання нового знання та Оцінювання (Рефлексія). Навчальна модель 5E забезпечує узгодженість різних стратегій викладання, забезпечує зв'язок між навчальними діяльностями та допомагає викладачам приймати рішення щодо взаємодії зі студентами. Порівняно з традиційними моделями навчання, навчальний цикл 5Е призводить до більших переваг щодо здатності студентів до дослідницької діяльності (https://knowledgequest.aasl.org/the-5-es-of-inquirybased-learning/).

У Таблиці 1 наведено приклад навчального кейсу iз змістового модуля «Елементи математичної логіки», розробленого на основі зазначеного підходу.

Таблицяя 1

\section{Навчальний кейс 3 модуля «Елементи математичної логіки»}

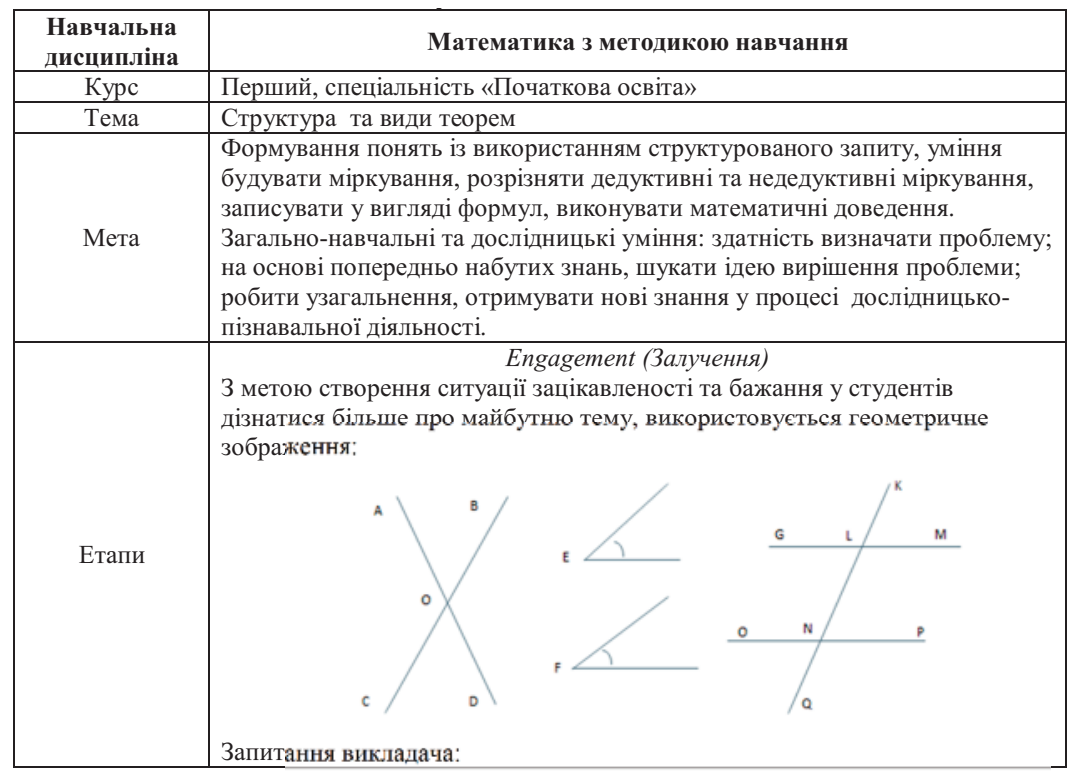




\begin{tabular}{|c|c|}
\hline & $\begin{array}{l}\text { Які твердження (теореми) можна сформулювати, використовуючи подані } \\
\text { зображення (використовується інтерактивна дошка Рadlet, презентація } \\
\text { PоwеrРоint). } \\
\text { Яка структура цих тверджень? } \\
\text { Які з них будуть істинні, а які - хибні? } \\
\text { Як ці твердження можна записати у вигляді формул? } \\
\text { Використовуючи сформульовані твердження, викладач пропонує } \\
\text { студентам визначити характеристичні ознаки теорем, їх структуру та } \\
\text { види. } \\
\text { Для більш ефективного залучення студентів використовуються } \\
\text { регуляторні картки. }\end{array}$ \\
\hline & $\begin{array}{l}\text { Exploration (Дослідження) } \\
\text { На основі аналізу сформульованих тверджень, використовуючи свої } \\
\text { попередні знання, студенти самостійно (можливо за інструкції викладача) } \\
\text { підходять до відповідей на питання: } \\
\text { - які твердження визначаються як теореми; } \\
\text { - які характеристичні ознаки та структура теорем; } \\
\text { - які є види теорем; } \\
\text { - яким способом визначається істинність чи хибність таких тверджень. } \\
\text { Викладач координує процес дослідження студентів за допомогою } \\
\text { регуляторних карток. }\end{array}$ \\
\hline & $\begin{array}{l}\text { Explanation (Пояснення) } \\
\text { Студенти надають строге математичне пояснення характеристичним } \\
\text { ознакам теорем, їх структурі та видам; будують власні міркування, } \\
\text { визначають їх істинність чи хибність. } \\
\text { Викладач, у разі необхідності, відповідними запитаннями допомагає } \\
\text { студентам виконати таке пояснення (доведення), заохочуючи, однак, } \\
\text { студентів зробити це самостійно. }\end{array}$ \\
\hline & $\begin{array}{l}\text { Elaboration (Отримання нового знання) } \\
\text { На цьому етапі студентам пропонується застосовувати своє нове } \\
\text { розуміння понять, одночасно удосконалюючи нові уміння: } \\
\text { 1. Ознаки теорем, структура та види теорем. } \\
\text { 2. Закон контрапозиції. } \\
\text { 3. Дедуктивні міркування. } \\
\text { 4. Запис тверджень за допомогою математичних формул. } \\
\text { Студенти під керівництвом викладача активно працюють над } \\
\text { закріпленням своїх щойно отриманих нових знань. }\end{array}$ \\
\hline $\begin{array}{c}\text { Очікуваний } \\
\text { результат }\end{array}$ & $\begin{array}{l}\text { Evaluation (Рефлексія) } \\
\text { 1. Чи повністю розв'язане поставлене завдання? } \\
\text { 2. Чи маємо ми чітке уявлення про ознаки теорем, структуру та види } \\
\text { теорем? } \\
\text { 3. Чи вміємо формулювати відповідні твердження, записувати за } \\
\text { допомогою математичної символіки, здійснювати узагальнення та } \\
\text { доведення? } \\
\text { Отримання студентами нових знань та умінь у процесі дослідницько- } \\
\text { пізнавальної діяльності. Формування математичних та загальних } \\
\text { компетенцій. } \\
\text { Етап рефлексії заохочує студентів самостійно оцінювати свої розуміння та } \\
\text { здібності, а також надає можливість викладачу оцінити успіхи студентів у } \\
\text { досягненні навчальної мети. }\end{array}$ \\
\hline $\begin{array}{c}\text { Кількість } \\
\text { годин }\end{array}$ & 1 академічна година \\
\hline
\end{tabular}


продовження Таблиці 1

\begin{tabular}{|c|l|}
\hline $\begin{array}{c}\text { Використання } \\
\text { цифрових } \\
\text { технологій }\end{array}$ & $\begin{array}{l}\text { Комп’ютер, доступ до Інтернет, смарт-дошка, інтерактивна дошка Padlet, } \\
\text { презентація РоwerPoint. }\end{array}$ \\
\hline $\begin{array}{c}\text { Інше } \\
\text { обладнання }\end{array}$ & Крейда, дошка \\
\hline
\end{tabular}

Планування занять 3 математики із використанням різних рівнів запиту та зазначеної моделі 5Е детально розглядались і обговорювались під час тренінгів спільноти викладачів університету. Плануючи такі заняття в процесі викладання математики автор ставив за мету забезпечити концептуальне розуміння математики, зокрема основ математичної логіки, шляхом впровадження інноваційних технологій, що базуються на підході IBME, формування математичної компетентності студентів. Ключовим завданням було покращення рівня математичної освіти, формування у студентів навчально-дослідницьких умінь і навичок. У процесі навчання студенти додатково ставили свої питання до теми, до кожного етапу пропонували відповідні регуляторні картки. Діяльність спонукала їх до проведення дослідження. Студенти самостійно, частково 3 підказкою викладача, вчилися правильно формулювати математичні твердження та висловлення, проводити різні етапи дослідження, формулювати припущення, робити узагальнення, виконувати пояснення i доведення, використовувати отримані нові знання на конкретних прикладах розв'язування задач. Наприкінці кожного заняття проводилось опитування студентів: «Чи була діяльність корисною? Чому?», «Чи спонукала до дослідження? Як?».

На завершальному етапі педагогічного дослідження було проведено опитування студентів 3 метою визначення стану сформованості дослідницьких умінь та зацікавленості у подальшому розвитку дослідницьких умінь в процесі навчання математики. Опитування засвідчило, що 27\% студентів вважають себе достатньо обізнаними у питанні формування дослідницьких умінь. Це переважно ті студенти, 
які мають високу мотивацію до навчання. Більшість визначає свій рівень готовності до науково-дослідницької роботи як частково готовий (70\%). Зросла кількість студентів, які готові висловлювати свої ідеї, припущення, якщо виникають труднощі при розв’ язуванні задачі (44\%) і зменшилась частка тих, хто звернеться за підказкою до викладача (24\%). Більшість студентів активно долучалась до вирішення поставлених питань і завдань. Усі студенти констатували, що робота з використанням дослідницько-пізнавального підходу дала змогу відчути впевненість у власних силах під час вивчення нового матеріалу, спонукала до самостійної роботи, допомогла в актуалізації набутих раніше знань. В результаті математичний матеріал став доступнішим для запам'ятовування. Абсолютна більшість виявила зацікавленість у подальшому розвитку дослідницьких умінь в процесі навчання математики (89\%).

\section{Висновки}

Вивчення стану сформованості навчальнодослідницьких умінь студентів першого курсу спеціальності «Початкова освіта» Педагогічного інституту Київського університету імені Бориса Грінченка підтвердило актуальність і доцільність обраної теми. В процесі навчання математики нами виявлено зростання зацікавленості студентів навчально-дослідницькою роботою. Підвищилась мотивація щодо вивчення математики.

Результати проведеного педагогічного дослідження показали, що формування навчально-дослідницьких умінь майбутніх вчителів початкової школи має здійснюватися в навчально-виховному процесі із застосуванням інноваційних підходів. Для розвитку дослідницьких умінь студентів на даний час вже не достатньо використовувати лише окремі методи і форми навчання, необхідно розглядати весь процес навчання 3 позиції дослідницько-пізнавального підходу. Причому це стосується не тільки навчання математики $\mathrm{i}$ природничих наук, а й інших навчальних дисциплін. 
Навчання студентів із застосуванням дослідницькопізнавального підходу, коли ідеї дослідництва органічно вплетені в усі форми навчального процесу: лекції, семінарські заняття, практичні та лабораторні роботи, індивідуальні або групові пошукові роботи, використання спеціально підготовленої системи питань, вправ і задач, а також інструментів сучасних інформаційно-комунікативних технологій, сприятиме формуванню і розвитку навчальнодослідницьких умінь студентів. Такий підхід вимагає відповідного рівня готовності викладачів вищої школи до означеного виду діяльності, побудови системи викладання навчальних предметів, у т.ч. математики, що базується на дослідницько-пізнавальному підході, розробки необхідних методик і матеріалів для професійного розвитку викладачів (організація конференцій, семінарів, майстер-класів та ін.).

Дослідження, результати якого викладені в статті, проведено в рамках проекту «Партнерство для навчання та викладання математики в університеті» (PLATINUM) програми СС Еразмус + КА203 - Стратегічне партнерство для вищої освіти, 2018-1-NO01-KА203-038887. Ця стаття відображає лише погляди автора, і Європейська Комісія не може нести відповідальність за будь-яке використання інформації, що міститься в ній.

\section{Література}

1. Dorier J.L. \& Maass K. Inquiry-Based Mathematics Education. In S. Lerman (Ed.), Encyclopedia of mathematics education, Amsterdam, Holland: Springer, 2014, p. 300-303.

2. Гончаренко С.У. Український педагогічний словник / голов. ред. С. Головко. Київ : Либідь, 1997. 373 с.

3. Jaworski B. Inquiry-based practice in university mathematics teaching development, In D. Potari and O. Chapman, International Handbook of Mathematics Teacher Education, Leiden, The Netherlands: Brill, 2019. Vol 1, p. 275-302. 
4. Мажуга Ю.І. Методико-математична компетентність майбутніх учителів початкової школи, вплив та значення математичної логіки у іiі формуванні. Матеріали XXIII Міжнародної науково-практичної інтернет-конференції «Тенденції та перспективи розвитку науки і освіти в умовах глобалізації» (Переяслав-Хмельницький, 31 жовтня 2017). Вип. 23. С. 125-131.

5. Vygotsky L.S. Mind in Society: The development of higher psychological processes. Cambridge, MA: Harvard University Press, 1978. 159 p.

\section{Мажуга Ю.I.}

\section{Формування дослідницьких умінь майбутніх вчителів початкової школи в процесі навчання математики}

\section{Анотація.}

У статті розглянуто проблему формування дослідницьких умінь студентів - майбутніх учителів початкової школи. Узагальнено погляди науковців на класифікацію та сутність навчально-дослідницьких умінь. Проаналізовано роль дослідницько-пізнавального підходу у формуванні навчально-дослідницьких умінь студентів в процесі викладання математики. Запропоновано ефективну методику формування навчально-дослідницьких умінь студентів у процесі викладання математики із застосуванням дослідницько-пізнавального підходу. У публікації використано матеріали дослідження, проведеного під час викладання математики студентам - майбутнім учителям початкової школи 3 використанням дослідницькопізнавального підходу.

Ключові слова: дослідницькі уміння, дослідницькопізнавальний підхід, дослідницько-пізнавальний підхід у навчанні математики, формування навчально-дослідницьких умінь учителя початкової школи. 


\section{Мажуга Ю.И.}

\section{Формирование исследовательских умений будущих учителей начальной школы в процессе обучения математике}

\section{Аннотация.}

В статье рассмотрена проблема формирования исследовательских умений студентов - будущих учителей начальной школы. Обобщены взгляды ученых на классификацию и сущность учебно-исследовательских умений. Проанализирована роль исследовательского подхода в формировании учебно-исследовательских умений студентов в процессе преподавания математики. Предложена эффективная методика формирования учебноисследовательских умений студентов в процессе преподавания математики с применением исследовательского подхода. В публикации использованы материалы исследования, проведенного во время преподавания математики студентам - будущим учителям начальной школы с использованием исследовательского подхода.

Ключевые слова: исследовательские умения, исследовательский подход, исследовательский подход в обучении математике, формирование учебноисследовательских умений учителя начальной школы. 